\title{
THE INFLUENCE OF EFFECTIVE RAINFALL ON MODELED RUNOFF HYDROGRAPH
}

\author{
MOJCA ŠRAJ, LUKA DIRNBEK, MITJA BRILLY
}

University of Ljubljana, Faculty of Civil and Geodetic Engineering, Ljubljana, Slovenia; Mailto: mojca.sraj@fgg.uni-lj.si

\begin{abstract}
Influence of the pattern of effective rainfall on modeled hydrograph was investigated in the study. The modelling was performed with the U.S. Army Corps of Engineers hydrograph package HEC-HMS 3.2 and calibrated and validated on measured hydrographs of Glinscica watershed. Six different models of rainfall loss were applied and their effect on modeled hydrograph was evaluated. Peak discharge, time of peak discharge and runoff volume were compared. The best results with the lowest RMSE in the study was obtained with the SCS curve number loss method. Also synthetic hyetographs of different probability and duration were used. Three positions of the maximum rainfall intensity at 25,50 and $75 \%$ of the rainfall duration were applied. The results showed essential differences in simulated time to peak and also differences in peak discharge. The differences in time to peak increases considerably with the increasing of the rainfall duration. Finally, the results of constant intensity distribution of rainfall of different durations were compared with those obtained with typical rainfall distribution with the position of the maximum intensity at $50 \%$. Results showed considerable differences in peak discharge and time to peak by longer durations of the rainfall.
\end{abstract}

KEY WORDS: Rainfall Loss Model, Rainfall Temporal Variability, Maximum Rainfall Position, RainfallRunoff Relationship, Synthetic Hyetograph, HEC-HMS.

Mojca Šraj, Luka Dirnbek, Mitja Brilly: VPLYV EFEKTÍVNYCH ZRÁŽOK NA MODELOVANÝ HYDROGRAF ODTOKU. J. Hydrol. Hydromech., 58, 2010, 1; 26 lit., 5 obr., 9 tab.

Práca obsahuje výsledky výskumu vplyvu efektívnych zrážok na modelovaný hydrograf. Odtok bol modelovaný pomocou nástroja U.S. Army Corps of Engineers hydrograph package HEC-HMS 3.2, potom kalibrovaný a verifikovaný na meraných hydrografoch povodia Glinscica.

Vplyv zrážok na modelovaný hydrograf bol vypočítaný pre šest’ rôznych modelov priebehu zrážok. Porovnali sme maximálne prietoky, časy ich trvania a odtečené množstvá. Najlepšie výsledky s najnižším RMSE sme získali s SCS modelom odtoku. Použili sme tiež syntetické hyetografy rozdielnej pravdepodobnosti a trvania. Použili sa tri polohy maximálnych intenzít zrážok; pre 25,50 a $75 \%$ ich trvania. Výsledky ukázali zásadný rozdiel $\mathrm{v}$ simulovaných časoch maximálneho prietoku a tiež rozdiely v maximálnych prietokoch. Rozdiely $\mathrm{v}$ časoch dosiahnutia maximálnych odtokov sa výrazne zvyšovali $\mathrm{s}$ časom trvania zrážky. Nakoniec sme porovnali výsledky výpočtov s konštantnými intenzitami rozdelenia $\mathrm{s}$ rôznym trvaním zrážky s tými, ktoré boli vypočítané $\mathrm{s}$ použitím typických rozdelení, $\mathrm{s}$ polohou maximálnej intenzity zrážok pri $50 \%$ ich trvania. Výsledky ukazujú významné rozdiely v maximálnych prietokoch a v časoch ich dosiahnutia v závislosti od trvania zrážky.

KLÚČCVÉ SLOVÁ: model odtoku, časová závislost' rozdelenia intenzít zrážok, čas maximálnej intenzity zrážky, závislost’ zrážka-odtok, syntetický hyetograf, HEC-HMS.

\section{Introduction}

The rainfall-runoff process is difficult to simulate precisely. Models usually use the concept of the effective rainfall where rainfall hyetograph is divided into losses and effective rainfall. The effective rainfall is then used as the model input to provide runoff hydrograph. Accurate representation of the effective rainfall is essential for rainfall-runoff models (El-Jabi, Sarraf 1991; Ball, 1994; Faures et al., 1995).

One of the problems of the ungauged basins is the estimation of loss rates. Loss rates depend on precipitation pattern and basin characteristics (DeVries, 1982). Also when we have some measurements, it is costly, time-consuming and difficult 
to measure all of the soil characteristics thoroughly enough and on the other hand, each rainfall event produces a different loss parameters. In fact, we usually have a limited range of measurements in practice.

The objective of this study was to evaluate the influence of effective rainfall on modeled runoff hydrograph. For this purpose the rainfall-runoff model of the Glinscica experimental watershed was made with the U.S. Army Corps of Engineers hydrograph package HEC-HMS 3.2. Six different models of rainfall loss (Infiltration index model, Horton model, Initial and uniform method, SCS method, Green Ampt method and Smith-Parlange method) were applied and their effect on modeled hydrograph was evaluated. Also the influence of rainfall intensity distribution and the maximum rainfall intensity position of synthetic hyetographs of different probability and duration were evaluated. To evaluate modeled results peak discharge, time-to-peak, runoff volume and root mean squared error (RMSE) of the modeled and measured hydrograph were compared.

\section{The study area}

The Glinscica watershed is one of three experimental watersheds in Slovenia (Rusjan et al., 2008; Sraj et al., 2008a; b). It is located in the central part of Slovenia and reaches into the eastern part of the urban area of the capital city of Ljubljana (Fig. 1). Because of the removal of rainfall water with a sewage system in urban area the orographic water divide does not coincide with precipitation drainage area (Brilly et al., 2006). The precipitation drainage area comprises $16,85 \mathrm{~km}^{2}$. The Glinscica stream has its source under the slopes of the hills of Polhograjsko hribovje at the altitude of $590 \mathrm{~m}$ and passes into the plain area of Ljubljana Plain. It flows into the Gradascica stream at the altitude of $209 \mathrm{~m}$ at the southernmost point of the watershed. The upper part of the watershed is a hilly region whereas the southern part is a plain area. A major tributary of the Glinscica is the Przanec creek. The wateshed is divided into three subwatersheds ( $\check{S}_{r a j}$, 2001).

The Glinscica watershed study site is equipped with rainfall station (Onset RG2-M), water station with the ultrasonic Doppler instrument (Starflow Unidata 6526 model) and a water quality multiprobe (Fig. 1).

The land use data were taken from the CORINE database (Heymann, 1993). Most of the watershed is forested $(48.6 \%)$, followed by agricultural land (22.9\%) (Brilly et al., 2006). The urbanised areas represents $19.6 \%$ of the Glinscica watershed. The soil types C and D (SCS classification) (Feldman, 2000 ) with low infiltration rate prevailed.

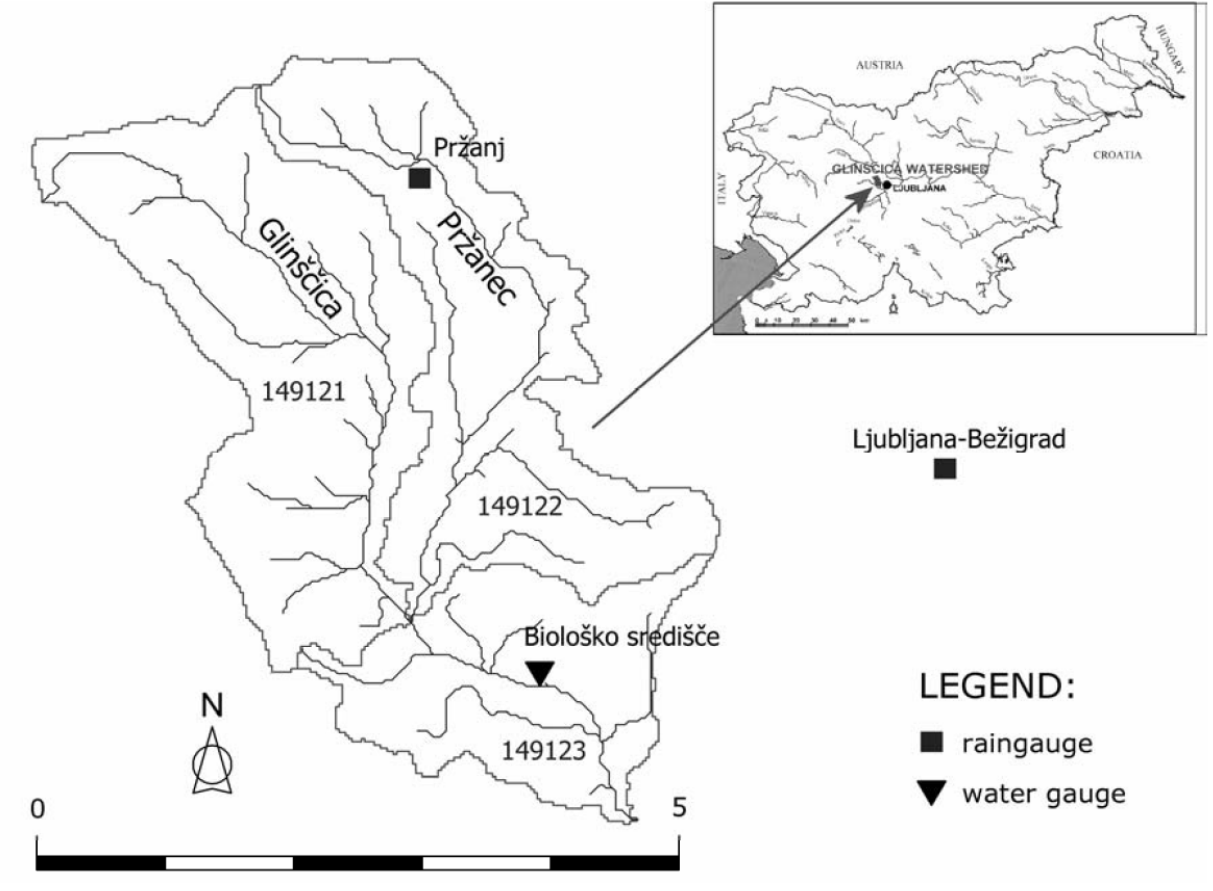

Fig. 1. Location of the Glinscica watershed and measurement stations. Obr. 1. Poloha povodia a meracích staníc v povodí Glinscica. 


\section{Methods}

\subsection{HEC-HMS modeling}

The HEC-HMS (Hydrologic Modeling System) software was developed at the Hydrologic Engineering Center of the US Army Corps of Engineers (HEC-HMS, 2009). It is used to simulate the rainfall-runoff processes and it was applied in many studies in different environments all over the world (Danil et al., 2005; Garcia et al., 2008; Unucka, Adamec, 2008). In the U.S.A. it is commonly used for computing design discharges (Marcus et al., 2007). HEC-HMS includes several models to account for the precipitation losses. Precipitation loss is calculated with selected model and the remaining precipitation represents effective hyetograph. The transformation of effective precipitation into runoff can be done with unit hydrograph models or conceptual kinematic-wave model of overland flow (Feldman, 2000).

The simulated hydrograph was calculated by applying on the unit hydrograph derived from the measured one. The model was calibrated on the selected measured runoff hydrograph. Measurements from November 2003 were used. The selected precipitation event lasted for forty hours and had the maximum intensity of $6 \mathrm{~mm} \mathrm{~h}^{-1}$. The total amount of the rain was $50.4 \mathrm{~mm}$. That rainfall event caused recorded peak discharge of $9.4 \mathrm{~m}^{3} \mathrm{~s}^{-1}$. The model was successfully validated on the measured hydrograph of January 2004. Six different models of rainfall loss were then applied with calibrated model. Loss models that are not included in the HEC-HMS package (Horton's model and $\Phi$-index model) were calculated manually.

\subsection{Infiltration models}

\section{F-index model}

The $\Phi$-index model is the simplest infiltration model used in hydrology. The method assumes that the infiltration rate is almost constant during the storm, so the total volume of the rainfall loss during the storm is estimated and distributed uniformly during the storm pattern (Viesmann et al., 1977).

The $\Phi$-index in our study was determined as the difference between the total gauged precipitation volume and the observed runoff volume from the measured hydrograph. The estimated $\Phi$-index value was $0.778 \mathrm{~mm} \mathrm{~h}^{-1}$. The results are showed in Fig. 2.

\section{Horton's infiltration model}

Horton's model is empirical and one of the most widely used infiltration models (Eq. (1)). Horton studied the infiltration process in the early 1930s (Horton, 1939). His equation indicates that infiltration tends to decrese in an exponential manner from the initial infiltration capacity $f_{0}$ to the final constant capacity $f_{c}$ :

$$
f(t)=f_{c}+\left(f_{0}-f_{c}\right) \cdot e^{-k t},
$$

where $f$ is the infiltration rate at time $t$ and $k-\mathrm{a}$ constant representing the rate of decrease in infiltration capacity. Parameters used in our model are presented in Tab. 1 and results in Fig. 2.

T a b l e 1. Parameters of the Horton's infiltration model. $\mathrm{T} a \mathrm{~b} \mathrm{u}$ l' k a 1. Parametre Hortonovej infiltračnej rovnice.

\begin{tabular}{lccc}
\hline Subbasin & 149121 & 149122 & 149123 \\
Area $\left[\mathrm{km}^{2}\right]$ & 7.20 & 5.99 & 3.66 \\
\hline$f_{0}\left[\mathrm{~mm} \mathrm{~h}^{-1}\right]$ & 7.60 & 7.60 & 7.60 \\
$f_{c}\left[\mathrm{~mm} \mathrm{~h}^{-1}\right]$ & 0.65 & 1.3 & 0.65 \\
$k[1 / \mathrm{h}]$ & 2.00 & 2.00 & 2.00 \\
\hline
\end{tabular}

\section{Initial and constant-rate loss model}

The concept of the initial and constant-rate model is that the maximum potential infiltration rate is constant. The initial loss is added to the model to represent interception and depresion storage (Feldman, 2000). The Soil Conservation Service SCS (1986) classified soils on the basis of infiltration rates. The classification is useful in the absence of measurements. Tab. 2 and Fig. 2 show initial and constant-rate losses of our model.

$\mathrm{T} \mathrm{a} \mathrm{b} 1 \mathrm{e} 2$. Losses of the initial and constant-rate loss model. T a b u l'k a 2. Odtoky vypočítane pomocou "počiatočného" modelu (initial loss) a modelu so stálym odtokom (constant rate).

\begin{tabular}{lccc}
\hline Subbasin & 149121 & 149122 & 149123 \\
\hline Initial loss $[\mathrm{mm}]$ & 14.10 & 10.17 & 5.62 \\
Constant rate $\left[\mathrm{mm} \mathrm{h}^{-1}\right]$ & 0.65 & 1.3 & 0.65 \\
\hline
\end{tabular}

\section{SCS curve number loss model}

The SCS model is an empirical model. Model has its origins in the unit hydrograph approach to rainfall-runoff modeling. It is particularly useful for ungauged watersheds because the parameters of the 

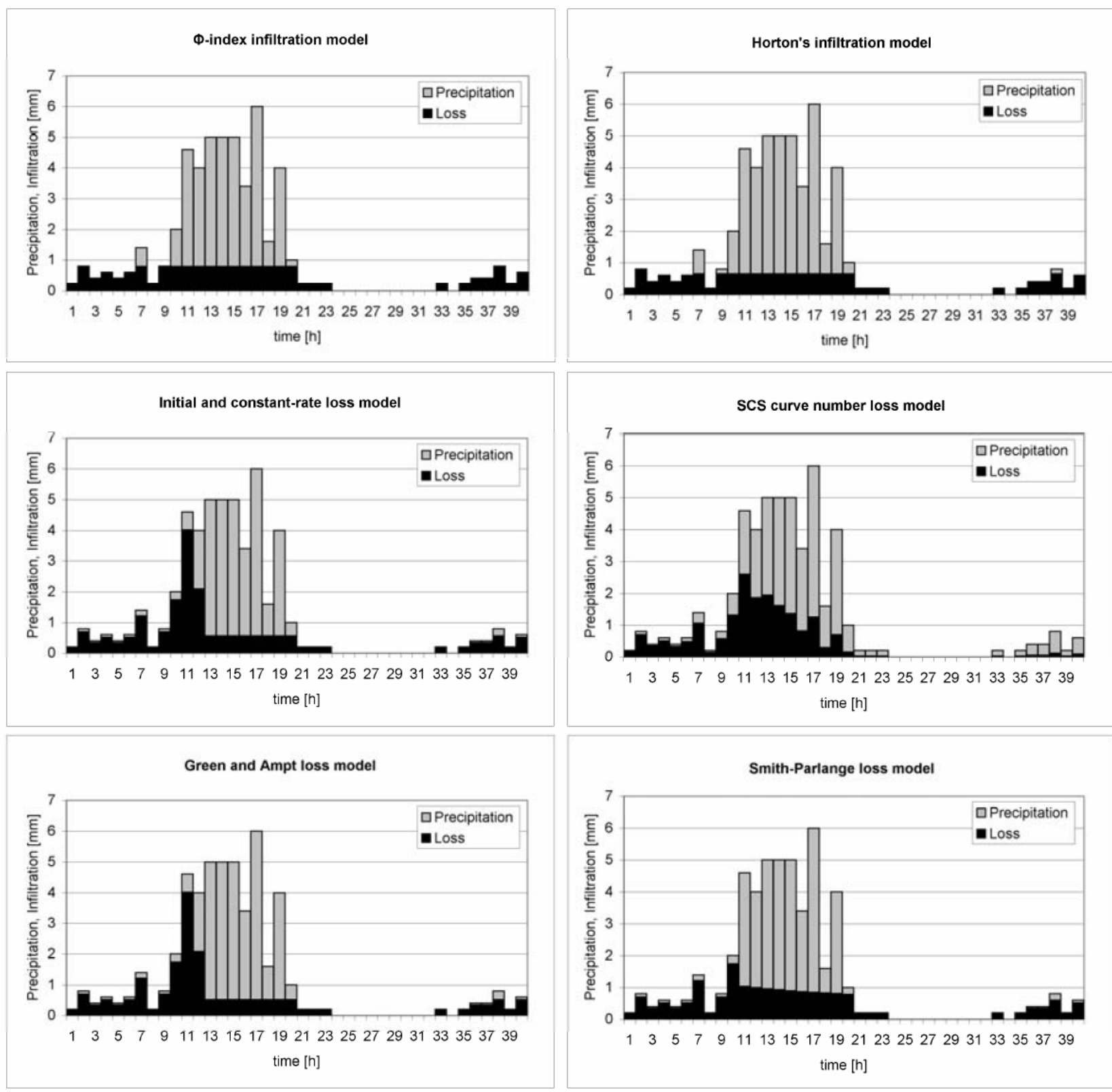

Fig. 2. Results of different loss models.

Obr. 2. Výsledky výpočtu rozdielnymi modelmi.

model have been related to the watershed characteristics. The SCS curve number model estimates cumulative rainfall excess $P_{e}$ as:

$P_{e}=\frac{\left(P-I_{a}\right)^{2}}{P-I_{a}+S}$,

where $P$ is accumulated rainfall depth at time $t, I_{a}-$ the initial abstraction and $S$ is potential maximum retention. $S$ and watershed characteristics are connected through curve number $C N$ as:
$S=\frac{25400-254 \cdot C N}{C N}$.

$C N$ values range from 30 to 98 and are tabulated by SCS $(1971,1986) . C N$ is a function of hydrologic soil group, cover type, treatment, hydrologic conditions and impervious area in the watershed (Feldman, 2000). SCS method is simple and stable and it is widely used all over the world (Feldman, 2000). Parameters used in our study are presented in Tab. 3 and resulted hyetograph in Fig. 2. 
$\mathrm{T} \mathrm{a} \mathrm{b} \mathrm{l} \mathrm{e} \mathrm{3.} \mathrm{Estimated} \mathrm{parameters} \mathrm{of} \mathrm{the} \mathrm{SCS} \mathrm{curve} \mathrm{number}$ loss model.

T a b u l'k a 3. Parametre určené pre SCS model.

\begin{tabular}{lccc}
\hline Subbasin & 149121 & 149122 & 149123 \\
\hline$I_{a}[\mathrm{~mm}]$ & 1.2 & 2.4 & 2.4 \\
$C N$ & 88 & 89 & 89 \\
\hline
\end{tabular}

\section{Green and Ampt loss model}

In 1911, Green and Ampt developed an analytical infiltration loss model (Eq. (4)) in which the wetting front moves vertically downwards from saturated soil to unsaturated soil. Their solution was based on one-dimensional vertical flow and was developed directly from Darcy's law (Delleur, 1999). The model computes the infiltration $f$ in a time interval as

$f=K\left[\frac{1+\left(\Phi-\Theta_{i}\right) \cdot S_{f}}{F_{t}}\right]$,

where $K$ is saturated hydraulic conductivity, $\left(\Phi-Q_{i}\right)$ - volume moisture deficit, $S_{f}$ - wetting front suction and $F_{t}$ - cumulative loss at time $t$. The infiltration rate $f$ decreases as $t$ increases.
The Green and Ampt infiltration model in HECHMS is a conceptual model. It includes also an initial abstraction which represents surface ponding not otherwise included in the model (Feldman, 2000). Estimated input parameters used in HECHMS model are showed in Tab. 4 and results in Fig. 2.

\section{Smith-Parlange model}

The Smith-Parlange model is based on Richard's equation for infiltration. The potential infiltration rate $f$ by Smith, Parlange (1978) is calculated as:

$$
f=K_{s} \frac{\exp \left(f_{\text {cum }} / B\right)}{\exp \left(f_{\text {cum }} / B\right)-1},
$$

where $K_{s}$ is effective saturated hydraulic conductivity in a time step, $f_{\text {cum }}$ - cumulative infiltration since the start of rain and $B$ is saturation deficit parameter combining the effective net capillary drive and the saturation deficit of the soil. Input parameters used in HEC-HMS model of Glinscica watershed are presented in Tab. 5 and results in Fig. 2.

T a b 1 e 4. Estimated HEC-HMS input parameters of the Green and Ampt infiltration model.

T a b u l' k a 4. Vstupné parametre HEC-HMS pre Greenov a Amptov infiltračný model; 1 - čast' povodia, 2 - počiatočný odtok, 3 - deficit obsahu vody, 4 - vodný potenciál na čele omáčania, 5 - hydraulická vodivost'.

\begin{tabular}{lccc}
\hline Subbasin $^{1)}$ & 149121 & 149122 & 149123 \\
\hline Initial loss $^{2)}[\mathrm{mm}]$ & 14.10 & 10.17 & 5.62 \\
Volume moisture deficit $^{3)}$ & 0 & 0 & 0 \\
Wetting front suction $^{4)}[\mathrm{mm}]$ & 714 & 636 & 714 \\
Hydraulic conductivity $^{5)}\left[\mathrm{mm} \mathrm{h}^{-1}\right]$ & 0.6 & 1.2 & 0.6 \\
\hline
\end{tabular}

$\mathrm{T}$ a $\mathrm{b} 1 \mathrm{e}$ 5. Estimated HEC-HMS input parameters of the Smith-Parlange infiltration model.

T a b u l'k a 5. Vstupné parametre HEC-HMS pre infiltračný model Smith-Parlange; 1 - čast' povodia, 2 - počiatočná vlhkost',

3 - reziduálna vlhkost', 4 - vlhkost' nasýtenia vodou, 5 - tlak vzduchu potrebný pre jeho vstup do pórov, 6 - rozdelenie pórov,

7 - hydraulická vodivost'.

\begin{tabular}{lccc}
\hline Subbasin $^{1)}$ & 149121 & 149122 & 149123 \\
\hline Initial content $^{2)}$ & 0.415 & 0.415 & 0.415 \\
Residual content $^{3)}$ & 0.09 & 0.109 & 0.09 \\
Saturated content $^{4)}$ & 0.475 & 0.43 & 0.475 \\
Bubbling pressure $^{5)}[\mathrm{mm}]$ & 856 & 794,8 & 856 \\
Pore distribution $^{6)}$ & 0.165 & 0.223 & 0.165 \\
Hydraulic conductivity $^{7)}\left[\mathrm{mm} \mathrm{h}^{-1}\right]$ & 0.6 & 1.2 & 0.6 \\
\hline
\end{tabular}

\subsection{Synthetic hyetographs}

Synthetic hyetographs are often used in hydrological modeling to estimate the design discharge (maximum peak discharge) for a given rainfall recurrence interval. They are also used when the precipitation data are not available or the records are too short. Synthetic hyetographs are rainfall tempo- 
ral patterns associated with a return period and often developed using intensity-duration-frequency (IDF) curves for rainfall events lasting from 30 minutes up to 24 hours. The Soil Conservation Service (SCS) 24-h hypothetical storm is example of synthetic design storm (DeVries, 1982). In synthetic hyetographs the maximum is usually placed in the middle of rainfall event regardless of rainfall duration. However, El-Jabi, Sarraf (1991) have proven for Moncton in Canada that the maximum rainfall intensity position should be considered in relation to the duration of the rainfall.

In the study, synthetic hyetographs of different probability and duration were used. Different positions of the maximum rainfall intensity were evaluated and also the constant intensity distribution of rainfall of different durations was applied and compared with typical rainfall distribution with the position of the maximum intensity at $50 \%$.

\section{Results and discussion}

\subsection{The influence of loss model}

In the study six different models of rainfall loss (Infiltration index model, Horton model, Initial and uniform method, SCS method, Green Ampt method and Smith-Parlange method) were compared (Dirnbek, 2009). Results are presented in Tab. 6, 7 and Fig. 3.

It was found that the SCS curve number loss model underestimates peak discharge by $7.6 \%$, but gives the best runoff volume and time-to-peak estimation (Tab. 6 and 7). In general, the SCS curve number loss method gave the best results with the lowest $R M S E\left(0.27 \mathrm{~m}^{3} \mathrm{~s}^{-1}\right)$.

All six loss methods gave applicable and comparable results with root mean squared error (RMSE) between 0.27 and $0.77 \mathrm{~m}^{3} \mathrm{~s}^{-1}$ (Tab. 7). Comparisons carried out using available data show no essential deviations between methods. Similar finding was reported also by Garklav, Oberg (1986) comparing inital and uniform method with exponential loss method.

The initial and uniform loss model or SCS model are well established and used widely and successfully in Slovenian practice and abroad. The reason is simplicity of use. Both models used only one or two parameters.

T a b l e 6. Results of different loss models for each subbasin.

T a b u l' k a 6 . Výsledky výpočtu rozdielnymi modelmi odtoku pre jednotlivé subpovodia; 1 - subpovodie, 2 - strata zo zrážky, 3 - efektívna zrážka, 4 - max. prietok, 5 - odtečený objem.

\begin{tabular}{cccccc}
\hline & Subbasin & $\begin{array}{c}\text { Precipitation loss } \\
{[\mathrm{mm}]}\end{array}$ & $\begin{array}{c}\text { Efective pre- } \\
\text { cipitation }^{3)} \\
{[\mathrm{mm}]}\end{array}$ & $\begin{array}{c}\text { Peak dis- } \\
\text { charge }^{4)} \\
{\left[\mathrm{m}^{3} \mathrm{~s}^{-1}\right]}\end{array}$ & $\begin{array}{c}\text { Runoff } \\
\text { volume }^{5)} \\
{\left[\mathrm{m}^{3}\right]}\end{array}$ \\
\hline \multirow{3}{*}{ F-index model } & 149121 & 16.82 & 33.58 & 4.3 & 241800 \\
& 149122 & 16.82 & 33.58 & 3.6 & 201100 \\
& 149123 & 16.82 & 33.58 & 2.2 & 122900 \\
\hline \multirow{3}{*}{ Horton's model } & 149121 & 14.88 & 35.52 & 4.2 & 255800 \\
& 149122 & 22.70 & 27.70 & 3.5 & 165900 \\
Initial and constant- & 149123 & 14.88 & 35.53 & 2.1 & 130000 \\
rate loss model & 149121 & 19.98 & 30.42 & 4.1 & 219100 \\
& 149122 & 19.78 & 30.62 & 3.3 & 183400 \\
SCS model & 149121 & 12.37 & 38.03 & 2.4 & 139200 \\
\hline \multirow{2}{*}{ Green and Ampt } & 149122 & 18.81 & 31.59 & 3.7 & 227300 \\
model & 149123 & 16.59 & 33.81 & 3.3 & 202400 \\
& 149121 & 16.59 & 33.81 & 2 & 123700 \\
\hline \multirow{2}{*}{ Smith-Parlange model } & 149122 & 19.56 & 30.84 & 4.1 & 222000 \\
& 149123 & 19.13 & 31.27 & 3.3 & 187300 \\
& 149121 & 11.91 & 38.49 & 2.4 & 140900 \\
\hline
\end{tabular}


The influence of effective rainfall on modeled runoff hydrograph

$\mathrm{T}$ a b 1 e 7. Comparison of the modeling results using different loss models with measured hydrograph at the outflow of the basin. $\mathrm{T}$ a b u l' k a 7. Porovnanie výsledkov modelovania s použitím rôznych modelov odtoku s meranými hydrografmi $\mathrm{v}$ konečnom profile povodia; 1 - max. prietok, 2 - rozdiel, 3 - odtečený objem, 4 - čas dosiahnutia maxima.

\begin{tabular}{cccccccc}
\hline & $\begin{array}{c}\text { Peak dis- } \\
\text { charge } \\
{\left[\mathrm{m}^{3} \mathrm{~s}^{-1}\right]}\end{array}$ & $\begin{array}{c}\text { Difference } \\
{[\%]}\end{array}$ & $\begin{array}{c}\text { Runoff } \\
\text { volume } \\
{\left[\mathrm{m}^{3}\right]}\end{array}$ & $\begin{array}{c}\text { Difference } \\
{[\%]}\end{array}$ & $\begin{array}{c}\text { Time of } \\
\text { peak }^{4)}\end{array}$ & $\begin{array}{c}\text { Difference } \\
{[\%]}\end{array}$ & $\begin{array}{c}\text { RMSE } \\
{\left[\mathrm{m}^{3} \mathrm{~s}^{-1}\right]}\end{array}$ \\
\hline $\begin{array}{c}\text { F-index model } \\
\text { Horton's model }\end{array}$ & 10.1 & 3.7 & 566000 & 1.9 & $18: 20$ & $-1: 50$ & 0.77 \\
$\begin{array}{c}\text { Initial and constant- } \\
\text { rate loss model }\end{array}$ & 9.76 & 0.2 & 551800 & -0.6 & $19: 00$ & $-1: 10$ & 0.58 \\
$\quad \begin{array}{l}\text { SCS model } \\
\text { Green and Ampt }\end{array}$ & 9.6 & -1.4 & 541600 & -2.5 & $18: 40$ & $-1: 30$ & 0.47 \\
$\quad \begin{array}{c}\text { model } \\
\text { Smith-Parlange model }\end{array}$ & 9.8 & -7.6 & 553400 & -0.3 & $20: 00$ & $-0: 10$ & 0.27 \\
\hline Measured hydrograph & 9.7 & -0.4 & 549200 & -1.1 & $18: 40$ & $-1: 30$ & 0.52 \\
\hline
\end{tabular}
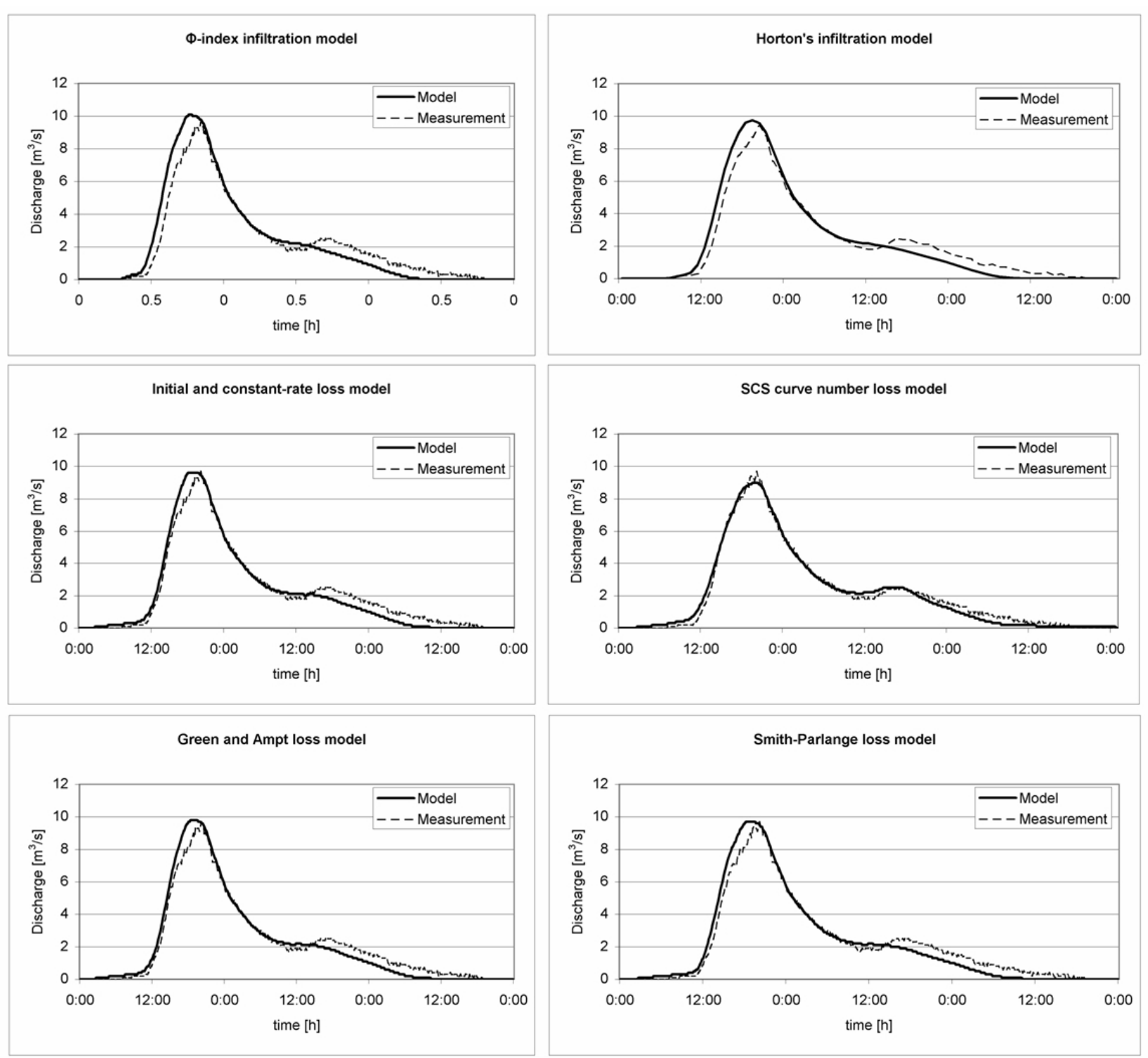

Fig. 3. Comparison of modeled hydrographs using different loss models with measured one.

Obr. 3. Porovnanie modelovaných hydrografov vypočítaných rozdielnymi modelmi s meraným hydrografom. 


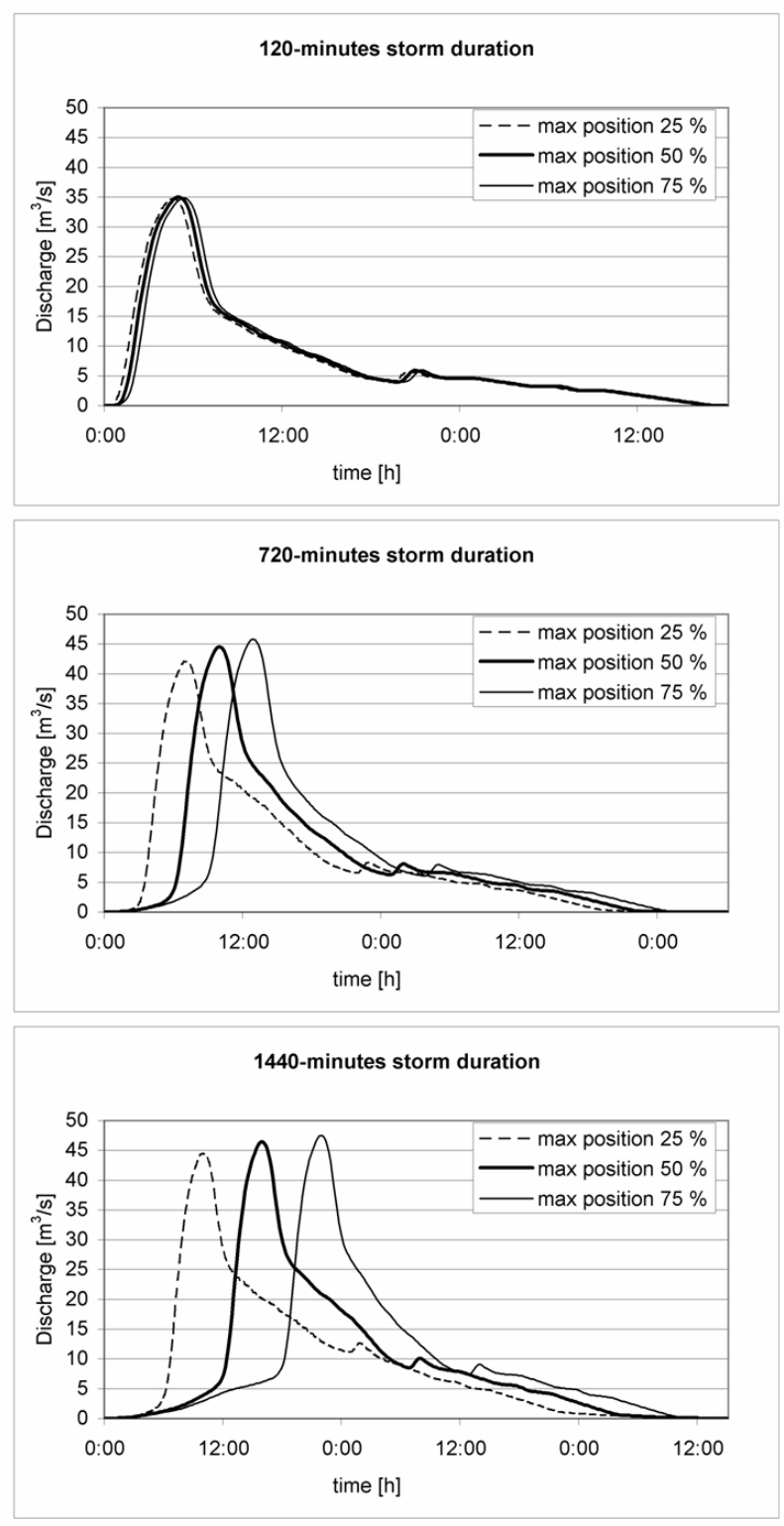

Fig. 4. Comparison of modeled results using different maximum rainfall intensity position and duration of synthetic hyetograph with the return period of 100 years.

Obr. 4. Porovnanie výsledkov modelovania s použitím rozdielnych rozdelení intenzít zrážok a ich trvania syntetického hyetografu s opakovaním raz za 100 rokov.

\subsection{The influence of maximum rainfall position of synthetic hyetograph}

Three positions of the maximum rainfall intensity at 25,50 and $75 \%$ of the rainfall duration were applied in the study. The rainfall durations were chosen in such a way that they were equal to, less than and more than the time of concetration of the watershed (the time needed for water to flow from the most remote point in a watershed to the watershed outlet). Initial and uniform loss method was applied and the same unit hydrograph as in previous cases.

The essential differences in time to peak of resulted hydrographs and also differences in peak discharge were established. The results demonstrate that the differences in time to peak increase considerably with the increasing of the rainfall duration (Fig. 4 and Tab. 8).

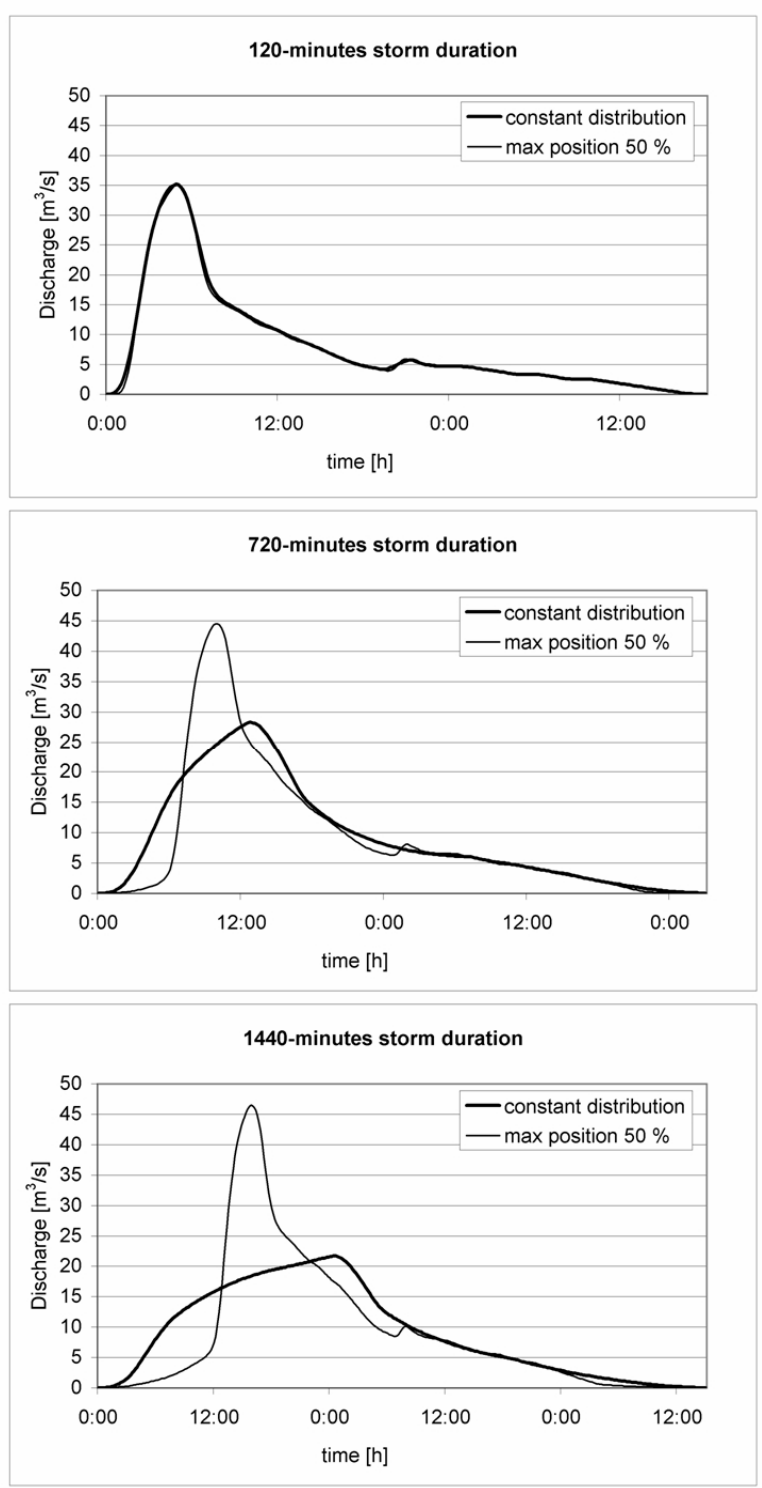

Fig. 5. Modeled results using constant rainfall distribution and typical rainfall distribution with maximum rainfall intensity position at $50 \%$ of the synthetic hyetograph with different durations and the return period of 100 years.

Obr. 5. Výsledky modelovania s použitím konštantného rozdelenia intenzity zrážok a s ich typickým rozdelením s polohou maximálnej intenzity na $50 \%$ trvania syntetického hyetografu $\mathrm{s}$ rozdielnym trvaním a s opakovaním raz za 100 rokov. 
Danil et al. (2005) have reported that the same discharge value can be derived from different combinations of storm duration and return period. They affirmed that the position of maximum rainfall intensity can be essential. Also, El-Jabi, Sarraf (1991) have established necessary to consider variable position of the maximum rainfall intensity position in relation to the duration of the rainfall.

\subsection{The influence of rainfall pattern of synthetic hyetograph}

Finally, the constant intensity of rainfall of different durations was applied. The results were compared with those obtained with typical rainfall distribution with the position of the maximum in- tensity at $50 \%$. There was no significant influence on runoff hydrograph by short rainfall durations, but extending of the rainfall duration caused the increasing of the difference in peak discharge and time to peak (Fig. 5 and Tab. 9). Furthermore, time to peak is shorter by temporaly variable pattern. Peak discharge of resulted hydrograph by 24-h constant rainfall intensity distribution was more than $100 \%$ lower than the one calculated with typical rainfall distribution.

We can conclude that temporal variability of rainfall produces greater peak discharge than does constant rainfal distribution. The same finding was established also by other authors (Ball, 1994; Singh, 1997; Maca, 2003).

$\mathrm{T} \mathrm{a} \mathrm{b} 1$ e 8. Modeled results using different maximum rainfall position and duration of the synthetic hyetograph with the return period of 100 years.

T a b u l'k a 8. Výsledky modelovania s rozdielnymi polohami maximálnej intenzity zrážky počas jej trvania a času trvania syntetického hyetografu s časom opakovania 100 rokov; 1 - poloha maximálnej intenzity zrážky, 2 - trvanie, 3 - max. prietok, 4 - odtečený objem, 5 - čas dosiahnutia maxima.

\begin{tabular}{|c|c|c|c|}
\hline & \multicolumn{3}{|c|}{ Maximum rainfall intensity position ${ }^{1)}$} \\
\hline & $25 \%$ & $50 \%$ & $75 \%$ \\
\hline \multicolumn{4}{|l|}{ 120-min duration ${ }^{2)}$} \\
\hline Peak discharge ${ }^{3)}\left[\mathrm{m}^{3} \mathrm{~s}^{-1}\right]$ & 34.7 & 35.0 & 34.9 \\
\hline Runoff volume ${ }^{4)}\left[\mathrm{m}^{3}\right]$ & 1167700 & 1180200 & 1181700 \\
\hline Time of peak ${ }^{5)}$ & $4: 30$ & 5:00 & $5: 20$ \\
\hline \multicolumn{4}{|l|}{ 720-min duration } \\
\hline Peak discharge $\left[\mathrm{m}^{3} \mathrm{~s}^{-1}\right]$ & 42.1 & 44.5 & 45.8 \\
\hline Runoff volume $\left[\mathrm{m}^{3}\right]$ & 1678700 & 1697300 & 1702500 \\
\hline Time of peak & 7:00 & $9: 50$ & $12: 50$ \\
\hline \multicolumn{4}{|l|}{ 1440-min duration } \\
\hline Peak discharge $\left[\mathrm{m}^{3} \mathrm{~s}^{-1}\right]$ & 44.5 & 46.5 & 47.5 \\
\hline Runoff volume $\left[\mathrm{m}^{3}\right]$ & 2027600 & 2041700 & 2046900 \\
\hline Time of peak & $9: 50$ & $15: 50$ & $21: 50$ \\
\hline
\end{tabular}

$\mathrm{T}$ a b 1 e 9. Comparison of the modeling results using constant rainfall distribution and typical rainfall distribution with maximum rainfall intensity position at $50 \%$ of the synthetic hyetograph with different durations and the return period of 100 years.

$\mathrm{T}$ a b u l' k a 9. Porovnanie výsledkov modelovania pre konštantné rozdelenie intenzity zrážky a typického rozdelenia s maximom intenzity zrážky pri 50 \% trvania syntetického hyetografu s opakovaním raz za 100 rokov; 1 - trvanie zrážky s opakovaním raz za 100 rokov, 2 - rozdelenie zrážky, 3 - maximálny prietok, 4 - odtečené množstvo, 5 - čas dosiahnutia maxima.

\begin{tabular}{lcccccc}
\hline & \multicolumn{5}{c}{ Storm duration of 100-year return period ${ }^{1)}[\mathrm{min}]$} \\
& \multicolumn{2}{c}{120} & \multicolumn{2}{c}{720} & \multicolumn{2}{c}{1440} \\
\hline Rainfall distribution $^{2)}$ & constant & $50 \%$ & constant & $50 \%$ & constant & $50 \%$ \\
Peak discharge $^{3)}\left[\mathrm{m}^{3} \mathrm{~s}^{-1}\right]$ & 35.2 & 35.0 & 28.3 & 44.5 & 21.7 & 46.5 \\
Runoff volume $^{4)}\left[\mathrm{m}^{3}\right]$ & 1209500 & 1180200 & 1689500 & 1697300 & 2025800 & 2041700 \\
Time of peak $^{5)}$ & $4: 50$ & $5: 00$ & $12: 50$ & $9: 50$ & $24: 30$ & $15: 50$ \\
\hline
\end{tabular}




\section{Conclusions}

The overall aim of the study was to evaluate the effect of effective rainfall on modeled hydrograph. We could expose three essential conlusions. (1) In our study all used loss models gave applicable and comparable results. The differences in peak discharge, time-to-peak and runoff volume have not varied in a great range. (2) On the other hand, it was found that the maximum rainfall position of the synthetic hyetograph has essential influence on runoff hydrograph, especially on time-to-peak. With the increasing of the rainfall duration the differences in time-to-peak increse considerable. (3) Rainfall pattern distribution has a great impact on runoff hydrograph. Constant rainfall intensity distribution produces essentially lower peaks than typical temporal rainfall distribution, especially by longer rainfall durations.

We can conclude that the pattern of precipitation excess can have a significant influence on the runoff hydrograph. Results of the model clearly refer to the importance of the excess hyetograph on runoff prediction. The influence is evident in peak discharge, time-to-peak and volume of the runoff hydrograph.

\section{List of symbols}

$B$ - saturation deficit parameter [mm],

CN - curve number [-],

$F_{t} \quad$ - cumulative loss at time $t[\mathrm{~mm}]$,

$f \quad-$ infiltration rate $\left[\mathrm{mm} \mathrm{h}^{-1}\right]$,

$f_{c} \quad$ - constant capacity $\left[\mathrm{mm} \mathrm{h}^{-1}\right]$,

$f_{\text {cum }}$ - cumulative infiltration since the start of the rain [mm],

$f_{0} \quad-$ initial infiltration capacity $\left[\mathrm{mm} \mathrm{h}^{-1}\right]$,

$I_{a} \quad$ - initial abstraction [mm],

$K \quad-$ saturated hydraulic conductivity $\left[\mathrm{mm} \mathrm{h}^{-1}\right]$,

$K_{s} \quad$ - effective saturated hydraulic conductivity in a time step $\left[\mathrm{mm} \mathrm{h}^{-1}\right]$,

$k-$ constant representing the rate of decrese in capacity $\left[\mathrm{h}^{-1}\right]$,

$P \quad$ - accumulated rainfall depth [mm],

$S \quad$ - potential maximum retention [mm],

$S_{f} \quad-$ wetting front suction $[\mathrm{mm}]$,

$t \quad-$ time $[\mathrm{h}]$

$\left(\Phi-Q_{i}\right)$ - volume moisture deficit [-]

\section{REFERENCES}

BALL J.E., 1994: The influence of storm temporal patterns on cathment response. J. Hydrol., 158, 285-303.

DELLEUR J.W., 1999: The handbook of groundwater engineering. CRC Press LCC, Boca Raton.

BRILLY M., RUSJAN S., VIDMAR A., 2006: Monitoring the impact of urbanisation on the Glinscica stream. Phys. Chem. Earth., 31, 17, 1089-1096.
DANIL E.I., MICHAS S.N., LAZARIDIS L.S., 2005: Hydrologic modeling for the determination of design discharges in ungauged basins. Global NEST Journal, 7, 3, 296-305.

DEVRIES J.J., 1982: Hydrologic Analysis of ungaged watersheds using HEC-1. US Army Corps of Engineers, Davis, CA.

DIRNBEK L., 2009: The effect of precipitation excess on runoff hydrograph. Unpublished diploma, University of Ljubljana.

EL-JABI N., SARRAF S., 1991: Effect of maximum rainfall position on rainfall-runoff relationship, ASCE Publ., 117, 5, 681-685.

FAURES J.M, GOODRICH D.C., WOOLHISER D.A., SOROOSHIAN S., 1995: Impact of small-csale spatial rainfall variability on runoff modeling. J. Hydrol., 173, 309-326.

FELDMAN A.D., 2000: Hydrologic modeling system HECHMS, Technical reference manual. US Army Corps of Engineers, Davis, CA.

GARCIA A., SAINZ A., REVILLA J.A., ALVAREZ C., JUANES J.A., PUENTE A., 2008: Surface water resources assessment in scarcely gauged basins in the north of Spain. J. Hydrol., 356, 312-326.

GARKLAVS G., OBERG K.A., 1986. Effect of rainfall excess calculations on modeled hydrograph accuracy and unithydrograph parameters. J. of American Water Resources Association, 22, 4, 565-572.

HEC-HMS, 2009: Online: http://www.hec.usace.army.mil/ (20. 3. 2009).

HEYMANN Y., 1993: CORINE land cover: Technical guide. Environment, Nuclear Safety and Civil Protection Series. Commission of the European Communities, Office for Official Publication of the European Communities, Luxembourg.

HORTON R.E., 1939: Analysis of runoff plot experiments with varying infiltration capacity. Trans. Am. Geophys. Union, Hydrology papers, 693-711.

MACA P., 2003: Movement of rainfall events in Prague area. J. Hydrol. Hydromech., 51, 2, 144-149.

MARCUS M., ANGEL J.R., YANG L., HEJAZI M.I., 2007: Changing estimates of design precipitation in Northeastern Illinois: Comparation between different sources and sensitivity analysis, J. Hydrol., 347, 211-222.

RUSJAN S., BRILLY M., MIKOŠ M., 2008: Flushing of nitrate from a forested watershed: An insight into hydrological nitrate mobilization mechanisms through seasonal high-frequency stream nitrate dynamics. J. Hydrol., 354 , $1-4,187-202$.

SINGH V.P., 1997: Effect of spatial and temporal variability in rainfall and watershed characteristics on stream flow hydrograph. Hydrol. Process., 11, 1649-1669.

SMITH R.E., PARLANGE J.Y., 1978: A parameter efficient hydrologic infiltration model. Water Resour. Res., 14, 3, 533-538.

SOIL CONSERVATION SERVICE (SCS), 1971: National engineering handbook, Section 4: Hydrology. USDA, Springfield, VA.

SOIL CONSERVATION SERVICE (SCS), 1986: Urban hydrology for small watersheds, Technical reference manual 55. USDA, Springfield, VA.

ŠRAJ M., 2001: Watershed coding system of the Republic of Slovenia. Acta Hydrotechnica, 19, 30, 3-24.

ŠRAJ M., BRILLY M., MIKOŠ M., 2008a: Rainfall interception by two deciduous Mediterranean forests of contrasting stature in Slovenia. Agric. for. meteorol., 148, 1, 121-134. 
ŠRAJ M., RUSJAN S., PETAN S., VIDMAR A., MIKOŠ M., GLOBEVNIK L., BRILLY M., 2008b: The experimental watersheds in Slovenia, IOP Conference Series, 4, 1-13.

UNUCKA J., ADAMEC M., 2008: Modeling of the land cover impact on the rainfall-runoff relations in the Olse catchment. J. Hydrol. Hydromech., 56, 4, 257-271.

VIESMANN W., KNAPP J.W., LEWIS G.L., HARBAUGH T.E., 1977: Introduction to hydrology. IEP A DunDonnelley Puplisher, New York.

Received 6 April 2009 Accepted 14 October 2009

VPLYV EFEKTIIVNYCH ZRÁŽOK NA MODELOVANÝ HYDROGRAF ODTOKU

\author{
Mojca Šraj, Luka Dirnbek, Mitja Brilly
}

Presné simulovanie zrážkoodtokového procesu je t’ažké. Koncepcia použitých modelov využiva tzv. efektívne zrážky; hyetograf zrážok je rozdelený na stratovú zložku a efektívnu zrážku. Efektívna zrážka je použitá ako vstup do modelu na výpočet hydrografu odtoku. Presné určenie efektívnej zrážky je pre zrážkoodtokové modely podstatné (El-Jabi, Sarraf 1991; Ball, 1994; Faures et al., 1995).

Ciel'om štúdie je výpočet vplyvu efektívnych zrážok na modelovaný hydrograf odtoku. Pre tieto účely bol vytvorený model experimentálneho povodia Glinscica s využitím nástroja U.S. Army Corps of Engineers hydrograph package HEC-HMS 3.2, ktorý bol kalibrovaný a verifikovaný $\mathrm{v}$ tomto povodí.

Povodie Glinscica je jedno z troch experimentálnych povodí v Slovinsku (Rusjan et al., 2008; Šraj et al., 2008a; b). Je lokalizované v centrálnej časti Slovinska a zasahuje do východnej časti areálu hlavného mesta Ljubljana. Jeho plocha je $16,85 \mathrm{~km}^{2}$. Tok Glinscica pramení pod svahmi pohoria Polhograjsko hribovje v madmorskej výške $590 \mathrm{~m}$ a tečie na plošinu Ljubljana. Vteká do toku Gradascica v nadmorskej výške 209 m v južnej časti povodia. Horná čast' povodia je hornatá, južná rovinatá. Hlavným prítokom Glinscice je tok Przanec. Povodie sa delí na tri subpovodia ( ̌raj, 2001). Povodie Glinscica je vybavené zrážkomerom (Onset RG2-M), vodomerná stanica ultrasonickým Dopplerovým prístrojom (Starflow Unidata 6526 model) a multisondou na meranie kvalitatívnych charakteristík. Údaje o využívaní krajiny boli získané $\mathrm{z}$ databázy CORINE (Heymann, 1993). Väčšia čast' povodia je zalesnená (48,6 \%), pol'nohospodárska pôda zaberá 22,9 \% (Brilly et al., 2006). Urbanizovaná plocha zaberá 19,6\% povodia Glinscica. Pôdy sú typu C a D (SCS klasifikácia) (Feldman, 2000) s prevažne nízkou intenzitou infiltrácie.

Simulovaný hydrograf bol vypočítaný pomocou jednotkového hydrografu, odvodeného z meraných hodnôt. Model bol kalibrovaný na vybraných nameraných odtokových hydrogramoch, boli použité merania $\mathrm{z}$ novembra 2003. Vybrané zrážkové udalosti trvali 40 hodín s maximálnou intenzitou $6 \mathrm{~mm} \mathrm{~h}^{-1}$. Zrážkový úhrn bol 50,4 mm. Táto zrážka spôsobila odtok, jeho nameraná hodnota bola $9,4 \mathrm{~m}^{3} \mathrm{~s}^{-1}$. Model bol úspešne verifikovaný na meranom hydrografe $\mathrm{v}$ januári 2004. Na tento kalibrovaný model bolo aplikovaných šest' rozdielnych modelov efektívnych zrážok. Tie modely, ktoré nie sú zahrnuté v balíku HEC-HMS (Hortonov model a $\Phi$-index model), boli počítané manuálne. Porovnali sme čas maximálneho prietoku, maximálny prietok a odtečený objem. Z porovnania nevyplynuli podstatné rozdiely medzi modelmi. Všetkých šest' metód určenia efektívnych zrážok dalo porovnatel'né výsledky s (RMSE) medzi 0,27 a 0,77 $\mathrm{m}^{3} \mathrm{~s}^{-1}$. Najlepšie výsledky s najmenším RMSE v danom prípade poskytla metóda SCS.

Syntetické hyetografy sa v modelovaní hydrologických javov často používajú na určenie návrhového prietoku (maximálnych prietokov) pre zrážku s daným časom opakovania. Používajú sa syntetické hyetografy rôznych pravdepodobností a trvania.

Trvanie zrážky bolo vybrané tak, aby bolo kratšie alebo rovnaké ako čas koncentrácie $\mathrm{v}$ povodí (je to čas potrebný pre prítok vody $\mathrm{z}$ navzdialenejšieho miesta povodia do miesta výtoku z povodia). $\mathrm{V}$ tejto štúdii boli použité tri polohy maximálnej intenzity zrážky pri 25,50 a $75 \%$ rozdielnych trvaní zrážky. $Z$ výsledkov vyplývajú značné rozdiely vo vrcholoch výsledných hydrografov a tiež rozdiely $\mathrm{v}$ maximálnych prietokoch. Rozdiely $\mathrm{v}$ časoch dosiahnutia maxím sa významne zvyšujú so zvyšujúcim sa trvaním zrážky.

Napokon boli použité konštantné intenzity zrážok s rôznym trvaním. Výsledky modelovania boli porovnané $\mathrm{s}$ tými, ktoré boli získané s typickým rozdelením zrážok, ked' bola poloha maxima pri 50 \% času trvania zrážok. Pri krátkych časoch trvania zrážok neboli zistené významné rozdiely $\mathrm{v}$ hydrografoch, ale zvyšujúc trvanie zrážok zvyšovali sa rozdiely medzi maximálnymi prietokmi a časmi po ich dosiahnutie. Napríklad, maximálny prietok vyvolaný $24 \mathrm{~h}$ zrážkou s konštantnou intenzitou bol podhodnotený o viac ako 100 \%. Záverom môžeme konštatovat', že časová variabilita zrážkok spôsobuje vyšší maximálny prietok ako zrážka s konštantnou intenzitou. Také isté výsledky uvádzajú aj iní autori (Ball, 1994; Singh, 1997; Maca, 2003).

Ciel'om tejto práce je vyhodnotit' vplyv priebehu zrážok na modelovaný hydrograf. Výsledky možno vyjadrit' tromi základnými závermi: (1) Všetky modely, použité v našej štúdii viedli $\mathrm{k}$ aplikovatel'ným a porovnatel'ným výsledkom. Rozdiely v maximálnych prietokoch, v časoch po ich dosiahnutie sa významne nemenili. (2) Na druhej strane bolo zistené, že poloha maximálnej intenzity zrážok na syntetických hyetografoch má zásadný vplyv na hydrografy odtoku, hlavne na čas dosiahnutia maximálneho odtoku. Tieto časy sa významnen zvyšujú so zvyšujúcim sa trvaním zrážok. (3) Rozdelenie intenzity zrážok má významný dopad na hydrograf odtoku. Zrážky $\mathrm{s}$ konštantnou intenzitou $\mathrm{v}$ zásade spôsobujú nižšie maximálne prietoky ako typické rozdelenie intenzít zrážok, hlavne pre dlhotrvajúce zrážky. 
Môžeme zhrnút': neštandardné rozdelenia intenzity zrážok môžu zásadným spôsobom ovplyvnit' hydrograf odtoku. Výsledky modelovania poukazujú na vplyv neštandardného priebehu intenzity zrážok na predpoved' odtoku. Tento vplyv je evidentný v maximálnom odtoku, $\mathrm{v}$ čase po jeho dosiahnutie a na objeme hydrografu odtoku.

\section{Zoznam symbolov}

$B \quad$ - parameter nedostatku nasýtenia [mm],

$C N \quad$ - číslo krivky [-],

$F_{t} \quad$ - kumulatívna strata v čase $t$ [mm],

$f \quad-$ infiltračná rýchlost' $\left[\mathrm{mm} \mathrm{h}^{-1}\right]$, $f_{c} \quad-$ stála kapacita $\left[\mathrm{mm} \mathrm{h}^{-1}\right]$,

$f_{\text {cum }} \quad$ - kumulatívna infiltrácia od začiatku zrážky [mm],

$f_{0} \quad-$ počiatočná rýchlost' infiltrácie $\left[\mathrm{mm} \mathrm{h}^{-1}\right]$,

$I_{a} \quad$ - počiatočný odtok [mm],

$K \quad$ - nasýtená hydraulická vodivost' $\left[\mathrm{mm} \mathrm{h}^{-1}\right]$,

$K_{s} \quad$ - efektívna nasýtená hydraulická vodivost' v danom časovom kroku $\left[\mathrm{mm} \mathrm{h}^{-1}\right]$,

$k \quad-$ konštanta, vyjadrujúca rýchlost' znižovania infiltrácie $\left[\mathrm{h}^{-1}\right]$,

$P \quad$ - akumulovaná vrstva zrážky [mm],

$S$ - potenciálna maximálna retencia [mm],

$S_{f} \quad-$ vodný potenciál na čele omáčania $[\mathrm{mm}]$,

$t \quad-$ čas [h],

$\left(\Phi-Q_{i}\right)-$ vlhkostný deficit v jednotkách objemu [-]. 